8-11-2019

\title{
Collective Survival Strategies and Anti-Colonial Practice in Ecosocial Work
}

\author{
Finn McLafferty Bell \\ The University Of Michigan \\ Mary Kate Dennis \\ University of Manitoba \\ Amy Krings \\ Loyola University Chicago, akrings@luc.edu
}

Follow this and additional works at: https://ecommons.luc.edu/socialwork_facpubs

Part of the Social Work Commons

\section{Author Manuscript}

This is a pre-publication author manuscript of the final, published article.

\section{Recommended Citation}

McLafferty Bell, Finn; Dennis, Mary Kate; and Krings, Amy. Collective Survival Strategies and Anti-Colonial Practice in Ecosocial Work. Journal of Community Practice, 27, 3-4: 279-295, 2019. Retrieved from Loyola eCommons, Social Work: School of Social Work Faculty Publications and Other Works, http://dx.doi.org/ $10.1080 / 10705422.2019 .1652947$

This Article is brought to you for free and open access by the Faculty Publications and Other Works by Department at Loyola eCommons. It has been accepted for inclusion in Social Work: School of Social Work Faculty Publications and Other Works by an authorized administrator of Loyola eCommons. For more information, please contact ecommons@luc.edu. c) (†) $\odot$

This work is licensed under a Creative Commons Attribution-Noncommercial-No Derivative Works 3.0 License. (c) Taylor \& Francis, 2019. 


\title{
Collective survival strategies and anti-colonial practice in ecosocial work
}

Finn McLafferty Bell, ${ }^{a}$ Mary Kate Dennis, ${ }^{b}$ and Amy Krings ${ }^{c}$

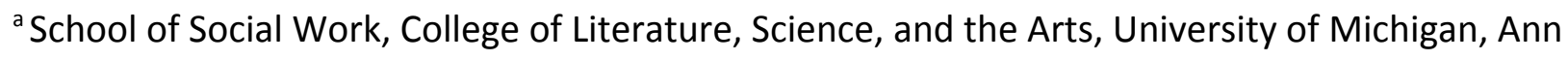
Arbor, Michigan, USA;

${ }^{b}$ Faculty of Social Work, University of Manitoba, Winnipeg, Manitoba, Canada;

'School of Social Work, Loyola University Chicago, Chicago, IL, USA

\section{Corresponding Author}

Finn McLafferty Bell, stephbel@umich.edu, School of Social Work, College of Literature, Science, and the Arts, University of Michigan, Ann Arbor, MI

\section{Copyright Agreement}

The Version of Record of this manuscript has been published and is available in the Journal of Community Practice, 2019, DOI: 10.1080/10705422.2019.1652947

\section{Complete Citation}

Finn McLafferty Bell, Mary Kate Dennis \& Amy Krings (2019): Collective survival strategies and anti-colonial practice in ecosocial work, Journal of Community Practice, DOI:

10.1080/10705422.2019.1652947

\begin{abstract}
Oppressed communities have long used strategies of caring for and protecting each other to ensure their collective survival. We argue for ecosocial workers to critically interrogate how agency, history, and culture structure environmental problems and our responses to them, by developing a resilience-based framework, collective survival strategies (CSS). CSS consider power, culture and history and build upon the strengths of oppressed communities facing global environmental changes. We challenge the dominant narrative of climate change as a "new" problem and connect it to colonization. We discuss implications by examining a social work program explicitly built on Indigenous knowledges and anti-colonial practice.
\end{abstract}

KEYWORDS: Climate change; environmental social work; environmental justice; Indigenous knowledges; community resilience 


\section{Collective survival strategies and anti-colonial practice in ecosocial work}

Finn McLafferty Bell, Mary Kate Dennis, and Amy Krings

The only way to survive is by taking care of one another, by recreating our relationships to one another. Grace Lee Boggs (1915-2015)

As social work confronts the severity of the ecological crisis, it becomes increasingly clear that the human- and social-focused logics that dominate the field are not sufficient. Liberal notions of rights and entitlements undergird social work as a discipline, but global environmental changes $^{1}$ also necessitate conversations about responsibilities and natural limits. While social work has long used systems theory and ecological perspectives to analyze persons in environment, we rarely acknowledge the natural environment in a meaningful way (Närhi \& Matthies, 2016). With the development of ecosocial work as a subfield, scholars and practitioners are developing ways to seriously consider the natural environment (Boetto, 2018). This has included a turn toward resilience (Case, 2017; Peeters, 2012a). Resilience is an essential framework for ecosocial work because by focusing on "the zone of stable functioning" for our ecosystems, resilience insists that we recognize natural limits and our responsibilities for staying within those natural limits (Cretney, 2014). However, resilience is not a normative concept, and incorporating resilience thinking into practice could make conditions more or less just (Walsh-Dilley, Wolford, \& McCarthy, 2016). Further, social scientists have rightly criticized resilience scholarship for its disregard for power, culture, and history (Cretney, 2014).

This article builds upon those debates. We develop a new framework, collective survival strategies (CSS), by thinking through a resilience approach that seriously considers power, culture, and history, and squarely focusing on the strengths of oppressed communities. In doing so, we recognize, as North Americans, that we cannot seriously consider power, culture, and history without directly addressing settler colonialism and embracing anti-colonial practice, particularly as ecosocial work incorporates Indigenous ${ }^{2}$ knowledges (Gray, Coates, \& Hetherington, 2007; Ramsay \& Boddy, 2017). By focusing on CSS, we learn from communities that have fought for environmental justice and collective survival for generations. After all, for many on this planet, the threat to collective survival did not begin in this new era of ecological crisis, and failing to recognize and learn from people who have prolonged experience in struggling for their collective survival could diminish the liberatory potential of ecosocial work.

This article focuses on the strategies that oppressed communities have historically used to ensure their collective survival. We argue that ecosocial work has a role in critically interrogating how agency, history, and culture structure environmental problems, as well as responses to those problems. In doing so, ecosocial workers can humbly learn from oppressed 
communities to uplift and enable their work. Hence, we start by critically examining resilience, including its varied definitions and applications. We then consider Indigenous conceptualizations of climate change that connect it to the colonization of North America. Next, we briefly examine the existing scholarship on ecosocial work and the importance of considering history, culture, and agency. We then present a framework, CSS, by which to understand a historically and culturally relevant approach to resilience that acknowledges both structural forces that have created the climate crisis and the agency that people continue to exercise in organizing for their own collective survival. Finally, we discuss practice implications through an examination of a social work program explicitly built upon Indigenous knowledges and anti-colonial practice.

We are a collective of scholars concerned about the impact of environmental injustice on oppressed communities that social workers are ethically bound to serve (Canadian Association of Social Workers [CASW], 2005; National Association of Social Workers [NASW], 2017), as well as on all other beings. Our diverse social locations, including as settlers and Indigenous, as clinicians and organizers, give us different starting points in considering the sources of environmental degradation and what is yet to be done. This article is the result of us grappling with each other, and with so many significant others, on these existential questions.

\section{Resilience}

Ecosocial work takes on the natural environment in a way that social work more broadly has generally neglected (Boetto, 2018). Ecosocial work's use of resilience is an important part of this shift. Resilience emerged from complex systems theory (Chandler, 2014; Vrasti \& Michelsen, 2017) and refers to "the capacity of a system to absorb disturbance and reorganize while undergoing change so as to still retain essentially the same function, structure, identity, and feedbacks" (Walker et al., 2004 in Peeters, 2012a, p. 16). Yet, the articulation and application of resilience varies greatly (Cretney, 2014), and the usage of resilience across academic disciplines, policy realms, and popular discourse are contested (Boonstra, 2016; Davoudi, Brooks, \& Mehmood, 2013; Hornborg, 2013; Ingalls \& Stedman, 2016; Vrasti \& Michelsen, 2017). Resilience emerged in engineering and ecology, but it was soon adopted as a framework to understand the nexus between the social and the ecological (Davoudi et al., 2013). However, with the application of the scientific concept of resilience onto social actors came a number of critiques from social scientists (Boonstra, 2016; Fabinyi, Evans, \& Foale, 2014; Ingalls \& Stedman, 2016). Social scientists argued that resilience frameworks have not seriously considered power, culture, and agency (Boonstra, 2016; Fabinyi et al., 2014; Ingalls \& Stedman, 2016; Ungar, Ghazinour, \& Richter, 2013).

Nonetheless, the development in resilience discourse that has provoked the most controversy is the cooptation of resilience by neoliberal forces, wherein individuals and groups 
are expected to continually build their capacity to "bounce back" from the crises and depredations endemic to neoliberal capitalist society (Cretney, 2014; Hornborg, 2013). The ascent of community resilience - defined as "a process of adaptation in a community following a disruption" (Cretney, 2014, p. 629) - as a dominant goal for disaster response by governmental and foundation actors has proved particularly controversial (Cretney, 2014; Tierney, 2015).

Tierney (2015) incisively critiques community resilience discourse in disaster response as reifying inequality. Although community resilience is framed as a means to empower communities to take control of their circumstances in an uncertain world and build capacity to bounce back from disasters, too often community resilience discourse fails to acknowledge the historical and structural factors that are exposing communities to such risks, and take for granted that the status quo is a desired place to return (Tierney, 2015). Further, the neoliberal discourse on resilience does not take culture into account, both in terms of proposing universalizing interventions, and in terms of failing to draw from cultural traditions that have sustained oppressed communities and enabled their collective survival (Cretney, 2014; Ungar et al., 2013).

Tierney (2015) suggests that the same neoliberal policymakers who advance community resilience also created the climate crisis that they now assert only they can solve. Neoliberal proponents of community resilience see it as the only reasonable reaction to a world defined by disruption caused by rapid urbanization, climate change, and globalization. However, doing so naturalizes disruption and frames it is as inevitable. Contrary to some scientific and transformative articulations of resilience (Cretney, 2014; Hornborg, 2013), neoliberal proponents insist that instead of addressing the root causes of disasters, we must adapt to them. Thus, Tierney (2015) contends that "resilience discourse frames members of at-risk populations as increasingly pressured to adapt to depredations that are the direct result of the historic and contemporary forces of neoliberalization" (p. 1333). In this framework, resilient subjects are not political actors; they must constantly focus on adapting to external conditions, rather than changing those conditions. Again, it should be noted that resilience theorists challenge this neoliberal discourse, noting that all subjects are part of multiple systems, and simultaneously impact those systems and are impacted by them (Chandler, 2014; Davoudi et al., 2013).

Social scientific critiques of how resilience researchers represent the social world and how neoliberal ideologies have co-opted its use have strengthened social-ecological resilience frameworks. These critiques have caused resilience scholars to seriously wrestle with issues of power (Boonstra, 2016), agency (Davoudi et al., 2013), and culture (Cretney, 2014). In doing so, resilience scholars have established a body of evidence supporting the liberatory and transformative potential of a "resilience from below" (Vrasti \& Michelsen, 2017). 
We locate CSS as one practice of "resilience from below" that is a necessary step in recognizing and increasing marginalized communities' adaptive capacity. While CSS are a necessary component of building resilience, they are by no means sufficient in addressing environmental changes on their own. As local climates may change rapidly, CSS are not enough to ensure collective survival. Yet, they are an important component that draws upon oppressed communities' strengths and histories. We see CSS as part of a larger movement that uses resilience as a basis for climate justice organizing (Movement Generation, 2013). In addition, in the North American context, any resilience framework that seeks to seriously engage history, culture, and power in addressing global environmental change is incomplete without examining settler colonialism as the foundation upon which all of these forces are playing out. Thus, we need to address Indigenous conceptions of global environmental changes, including how they are continuations of colonization.

\section{Settler colonialism and climate change}

In his prolific writing on climate change, Indigenous philosopher, Whyte $(2016,2017))$, has challenged the dominant narrative propagated by mostly $4 \mathrm{~F}$. M. BELL ET AL. white environmentalists that climate change represents a coming dystopia that has heretofore not existed in the modern world. Rather, Whyte (2017) argues that many of the worst expected outcomes of a changing climate - species extinction, forced migration, hunger, disease, lack of clean water, rapidly shifting environmental changes - are all conditions that European invaders, settlers, and their descendants forced upon North American Indigenous people and continue to do so. Sharpe (2016) makes a parallel argument that we can only understand the current plight of AfricanAmericans in the US "in the wake" of slavery: how being violently ripped from their homelands (another massive change in climate) and enslaved has shaped their experiences.

It is important to understand that Whyte does not make this argument to minimize the dangerous effects of global environmental change, particularly as Indigenous peoples will continue to be impacted first and worst. Instead, Whyte (2016) wants us to take colonialism seriously as both a key cause of climate change and as a factor that prevents Indigenous and other people from effectively "adapting." Waziyatawin (2012) elaborates this paradox when noting that the climate crisis (as part of a series of converging crises) represents a decolonizing opportunity for Indigenous peoples, but also threatens the continuation of life on this planet, including Indigenous communities and all of the lifeways ${ }^{3}$ that support them.

Settler colonialism is distinct from other forms of colonialism in that the colonizers do not solely seek to export wealth from their colonies by exploiting its natural resources and native labor; rather, settler colonialism operates under a logic of elimination and domination: destroy to replace (Wolfe, 2006). Alfred (2009) argues this process began with the doctrine of terra nullius, 
or "empty lands" asserting that North America was not populated by humans before the arrival of Christian Europeans and rationalizing the dispossession of Indigenous peoples from their lands. Settler colonialism is fundamentally about land and resources. Settlers seek to destroy the native population, native culture, native ecologies, and native sovereignty in order to replace them with their own population, culture, ecologies, and institutions (Waziyatawin, 2012; Whyte, Caldwell, \& Schaefer, 2018). Settler colonialism is not an event that happened in the past; rather it is the structure of settler colonial societies, such as the United States, Canada, Australia, and Israel (Wolfe, 2006). In North America, the arrival and violent settling practices of Europeans brought a literal apocalypse to the Indigenous population. Population estimates are difficult to determine prior to 1492, and the devastating effects vary across tribal groups; however, the Indigenous population was reduced by roughly $80-90 \%$ by 1890 (Thornton, 2000).

Whyte (2016) shows that traditional Indigenous governance structures and ways of life are not only in tune with the natural environment, but also are eminently adaptable to fluxes in the natural environment. The continual removal and forced relocation of Indigenous peoples into smaller and smaller tracts of less desirable land caused not just immeasurable loss and grief but also a profound disconnection from an Earth-based way of life (Brewer \& Dennis, 2019). Further, the intentional destruction of Indigenous cultures through residential and boarding schools, religious conversion, and other means has disrupted the intergenerational flow of traditional environmental knowledge that teaches Indigenous peoples how to live in right relationship with all their relations in a specific place, thus ensuring collective survival (Hart, 2009; Waziyatawin, 2012).

The forced climate change of colonization is the foundation on which both the US and Canadian industrial societies were built, to the benefit of their settlers and settler descendants, and to the detriment of the planet due to the disproportionate responsibility that North America has in causing the global environmental changes that we see today. We cannot effectively address these changes without simultaneously dismantling one of the foundations on which they were built: colonialism.

We draw particular attention to climate change as a continuation of colonization, because in a rush to place global environmental change on the social work agenda - which is incredibly important and necessary - ecosocial work should not fail to acknowledge how the very real threat to collective survival is historically and culturally situated. Thus, climate change lands very differently on disparate groups, particularly for Indigenous people who have long experienced threats to their futurity. For many of the white environmentalists that Whyte (2017) challenges, threats to their collective survival as a people does indeed feel new, as generally white North Americans are not used to having their futurity threatened. Whyte et al. (2018) describe futurity as: 
the idea that members of a society ought to be able to experience that their own efforts and contributions to their society play a part in making it so that a vibrant future is possible for the coming generations ... Futurity [is] significant for Indigenous peoples, for one way of understanding settler colonialism is as a form of oppression that destroys Indigenous futurity. (p. 163)

In thinking about our futurity as a species, it is vital that ecosocial work attends to the ways that settlers have materially benefitted from the threat to Indigenous futurity.

\section{Ecosocial work: an emerging field}

Ecosocial work is a growing field of social work scholarship (Krings, Victor, Mathias, \& Perron, 2018; Mason, Shires, Arwood, \& Borst, 2017) and a means to promote environmental sustainability at all levels of practice (Norton, 2012). It draws upon a deep ecological awareness of humans' relationship with nature and the built environment and, thus, focuses on protecting and sustaining the natural environment in an equitable way (Gray et al., 2007). Ecosocial work helps to build community resilience, but endeavors to do so in service of social-political change rather than the status quo (Peeters, 2012b; Teixeira \& Krings, 2015). In their conceptual analysis, Ramsay and Boddy (2017) found that four key attributes define environmental social work: (1) the application of social work skills to the environment; (2) openness to different values and ways of being or doing, including learning from Indigenous cultures; (3) adopting a change orientation, which includes critiquing hegemony; and (4) working across boundaries and in multiple spaces, which includes working in multidisciplinary teams with communities and individuals. Gray et al. (2007) argue that ecosocial work "articulates and privileges local Indigenous cultures" (p. 56) through its emphasis on the importance of place, alternative worldviews, celebration of diversity, and sharing of knowledge related to humans' interdependence and connectedness to the Earth. As ecosocial work embraces Indigenous knowledges and practices, it is important to acknowledge the work of Indigenous scholars (Billiot et al., 2017), and seriously engage with the ways that colonialism has erased, and continues to erase, Indigenous knowledges and practices in favor of Western ones.

\section{The importance of history, culture, and agency}

Ecosocial work prioritizes social change, including in its orientation toward resilience (Case, 2017; Peeters, 2012b). To do so effectively, engaging seriously with the places that resilience frameworks have traditionally struggled - history, culture, and power - is essential. We agree with much of Tierney's (2015) critique of community resilience discourse as overemphasizing agency at the expense of structure, and yet, this critique leaves few options in 
terms of how marginalized communities can organize to protect and care for themselves. Her critique does not build on the strengths that communities have long held in surviving colonization, enslavement, exploitation and oppression, and it is profoundly demobilizing. Tierney critiques community resilience discourse for putting all of the focus on what marginalized groups need to do to make themselves resilient to disaster without acknowledging the historical and structural factors that put them at risk. Thus, Tierney is constructively demystifying history and structure on one hand, while completely disregarding individual and collective agency on the other. Further, neither community resilience discourse, nor Tierney's critique of it seriously consider culture as an enabler of collective survival. We examine how history, agency, and culture all need to be seriously considered in responding to environmental crises and how a focus on CSS does that.

\section{Historical context}

As discussed in Whyte's $(2016,2017)$ work, understanding the history that has brought us to this moment is essential to effectively addressing climate change. While Tierney (2015) argues that the world's poor, who are simultaneously most at risk from and least responsible for the ecological crisis, should not have to adapt, even if we were to take serious, commensurate global action now, the impacts of global environmental change will continue (Intergovernmental Panel on Climate Change [IPCC], 2018). Thus, understanding the historical roots of the ecological crisis - and how, for many oppressed communities, this is an intensification of already dystopian conditions - is key to understanding how those same communities can approach collective survival now, by building on many of the same practices that have enabled their collective survival thus far. For ecosocial work, the question then is: how can we learn from this history, including our place in it, and support oppressed communities in facilitating CSS? As Anishinaabe Elder, Art Solomon, explains:

In order to know where we are going, we need to know where we are. In order to know where we are, we need to know who we are. And, in order to know who we are, we need to know where we come from (in Hart et al., 2014, p. 7).

This matters because an ahistorical understanding of resilience to rapid change denies community members their ancestors' experiences of resisting, surviving, and continuing despite horrific conditions being imposed upon them by the same forces that are largely responsible for global environmental change.

\section{Understanding the tension between agency and structure}


Similar to the critique of community resilience discourse, Mullaly (1997) has criticized mainstream social work for paying insufficient attention to changing the structural factors that impact clients and communities. However, in bringing attention to structural factors, we must not lose sight of individual and collective agency. Agency is the foundation for self-determination, and collective agency, in the form of collective action for social change, is the only force powerful enough to change structural conditions, as ecosocial work recognizes (Närhi \& Matthies, 2016). An over-deterministic focus on structure produces incisive critiques of the world as it is while leaving little room for the political project of building the world that we want. CSS show the power of collective agency not just to directly overthrow oppression, but also to create liberated spaces where people are cared for and safe as a resistance to oppression.

\section{The importance of culture}

Ecosocial work has called for engagement with Indigenous cultures and traditional environmental knowledge (Gray et al., 2007; Ramsay \& Boddy, 2017), but we must take seriously how those cultures are situated within settler colonial states. Communities have maintained cultural practices despite attempts to violently destroy their traditions. This is true for people who were colonized, as well as people who were enslaved. For example, enslaved African women secretly braided okra and rice seeds into their hair to bring vital pieces of their culture with them through the Middle Passage (Bandele \& Myers, 2016). Culture is a strength upon which many communities have built their ability to survive and thrive despite oppressive conditions, which explains why cultural imperialism - convincing the colonized that their culture is inferior and that they must adopt the superior culture of their colonizers - is such a prevalent tool amongst oppressors (Said, 2012). As Nobel Peace Prize winner, Wangari Maathai, stated when discussing the violence of colonialism (Dater \& Merton, 2008):

Culture is coded wisdom. Wisdom that has been accumulated for thousands of years and generations .... All people have their own culture. But when you remove that culture from them, then you kill them in a way. You kill them. You kill a very large part of them.

As ecosocial work scholars recognize, attempts to help a community adapt to environmental change need to fit the unique culture(s) of that community, but they also need to consider what that culture has needed to survive.

\section{Collective survival strategies}

CSS are fundamentally about how communities protect and care for each other, and always have. Rather than representing an innovation, CSS are an old technology. There are five 
key components to CSS, as we define them. They are: (1) communal and cooperative, not individualistic; (2) rooted in place and existing cultural traditions; (3) focus on basic survival needs - food, water, shelter, protection, culture; (4) self-organized and autonomous - not reliant upon outside actors; and (5) address both quotidian and spectacular disasters - making everyday life better and reducing vulnerability to larger crises. First, the practice must be collective, not individualistic. CSS involve people working cooperatively for the good of the whole. This is a key distinction between CSS and the survivalist practices of predominantly white, male segments of the population who identify as "preppers" (Schneider-Mayerson, 2015). While preppers engage in survival practices that incorporate other components of CSS, the prepper narrative of the rugged individual who must engage in all-against-all warfare to survive is antithetical to CSS (Schneider-Mayerson, 2015).

Second, CSS are rooted in place and existing cultural traditions. There is no single universal approach to CSS because practices are tailored to meet unique needs in a particular place by the people themselves. For instance, Lakota elders living on the Pine Ridge Indian Reservation continue the traditions that they learned as children when their families were self-sufficient on their homesteads: raising animals, growing vegetables, and harvesting wild foods on the land as Lakota people have for millennia (Brewer \& Dennis, 2017). These harvesting trips taught children the location and Lakota names for wild foods, thereby helping them to maintain a place-based and spiritual connection to their food system. As older adults, they carry this knowledge and have the skills to achieve food security for younger generations on this reservation (Brewer \& Dennis, 2017). A social work approach to CSS recognizes the traditional environmental knowledge that people who are rooted in a specific place carry, and helps to remove the barriers that exist so that those people can exercise that knowledge.

Third, community survival strategies focus on basic human survival needs. These include food, shelter, water, protection, and culture. In the US, where a shifting racialized capitalist economy has left low-income Black communities without access to basic survival needs, struggles are increasingly, explicitly waged over control of food, land, and water (Krings, Kornberg, \& Lane, 2019; Krings \& Thomas, 2018). In describing Black-led agriculture work in Detroit, Quizar (2018) argues that "growers often characterize farming, accessing food, and having control over one's own food supply as issues of survival - of day-to-day livelihood and also more broadly of Black and poor people's survival" (p. 82). For some Black Detroiters, growing food is an important CSS because it entails reclaiming agricultural labor from its association with enslavement and exploitation as a site to build self-reliance and self-determination (Quizar, 2018; White, 2011, 2017).

Fourth, CSS are self-organized and autonomous; although they could receive assistance from outside actors, they are not created or led by governments or exogenous non-profits. 
Communities working to meet collective survival needs may form non-profits or apply for government funding to support their work, but they generally do so with a wariness of becoming dependent on such sources or giving them undue influence (Krings, Spencer, \& Jimenez, 2014). For example, some climate adaptation planning happening amongst Indigenous people in the US is being financially supported by the federal government, and yet, the initiatives are explicitly and unapologetically by and for Indigenous people (Whyte et al., 2018).

Finally, CSS are not just about preparing for spectacular disasters that may come; they are responses to the disastrousness of everyday life in so many communities. As disaster studies recognize, the destructiveness of what we call disasters are not anomalies, they are magnifications of the injustices and social vulnerabilities of everyday life (Klinenberg, 2015). CSS do make people more resilient to spectacular disasters, but, crucially, they do so by improving their everyday lives. Thus, CSS takes an inverse approach to a neoliberal conception of resilience, rather than focusing on how to "bounce back" to a supposedly stable and socially just point of stasis, CSS address the instability and injustice that is the lived reality in marginalized communities. In doing so, CSS reduce the community's social vulnerability to both quotidian and spectacular disasters. Going back to Detroit, Black food growers use that practice to reduce their reliance on precarious paid labor and to prevent health problems caused by lack of access to fresh, healthy food: two key factors in the disastrousness of everyday life for many low-income, Black Detroiters (Quizar, 2018; White, 2011). In case of disaster, bouncing back to the unjust and unstable status quo in Detroit is not a worthy goal, rather, farmers in the city are proactively changing the status quo by building food sovereignty in the Black community.

Again, CSS are fundamentally about how communities protect and care for each other. Particularly in communities that have long experienced oppression, exploitation, and colonization, these habits are what have enabled their collective survival thus far and are key to understanding how to continue into the future. These strategies happen at multiple levels and incorporate diverse tactics, which is essential in building resilience (Davoudi et al., 2013).

Protecting and caring for each other happens in both political and seemingly non-political realms. In order to address the root causes of injustice, communities need to address their oppressors directly or build alternative systems, called autonomous zones (Peña, 2005), whereby they can be free of their oppressor. Often both approaches must be undertaken for either to be successful. When oppressed groups manage to free themselves, but do not have already existing alternative systems or institutions, they run the risk of recreating their oppressor's system. When groups successfully build alternative, more just institutions, they often face state violence and repression, which they then need to confront or evade to continue their alternative institutions. 
Further, communities need a certain guarantee of rights to access means of survival, such as land and clean water (Walsh-Dilley et al., 2016). Hence, movements may start out with seemingly non-political aims, and yet find themselves engaging in power struggles in order to meet their survival needs. Walsh-Dilley et al. (2016) argue that by embracing food sovereignty's focus on communal rights, resilience scholars can meaningfully incorporate a power analysis into their framework while challenging liberal notions of individual rights.

\section{Anti-colonial practice and collective survival strategies}

Anti-colonial practice is a model that provides a way for ecosocial work to support CSS, while challenging colonialism, which is a root cause of the ecological crisis and hinders Indigenous communities' ability to adapt to environmental change. Anti-colonialism is a social, cultural, and political position rooted in the collective and common consciousness that colonialism was imposed and dominating (Hart, 2009). It is also the resistance that Indigenous people have enacted against colonial frameworks since colonialism began (Smith, 1999). One method of anticolonialism is the recovery and practice of traditional Indigenous knowledge while employing a critical analysis of colonialism.

Indigenism is one stance of anti-colonialism that, like CSS, is tied to a place and a time, as Indigenous people are bounded to a space from which their culture and values are derived. They do not occupy a place but are "children of that place" (Moore et al. in Hart, 2009, p. 33). Indigenous people have "the responsibility to practice kinship roles of their bioregional habitat, manifested through cultural beliefs, rituals and ceremonies that cherish biodiversity" (Hart, 2009, p. 33). Indigenism prioritizes Indigenous rights, and cultural traditions uphold these rights. Without rights, Indigenous people are prevented from exercising their responsibility of kinship roles and meeting their collective survival needs (Waziyatawin, 2012). Further, self-sufficiency is a necessary condition for Indigenous collective action (Tarrow, 1998 in Hart, 2009).

Anti-colonial practice builds social work capacity to support Indigenous communities in collectively surviving global environmental change in a way that is culturally centered, historically relevant, and focused on collective agency. While anti-colonial practice is an emerging framework in social work (Hart, Straka, \& Rowe, 2017), there are models we can look to of this framework in action. The Master of Social Work based in Indigenous Knowledges (MSW-IK) program at the University of Manitoba was created in response to the important need for social workers to explore and incorporate Indigenous forms of caring applicable to the unique circumstances of Indigenous people and their communities (Hart et al., 2014). Indigenous forms of caring are rooted in traditional values, social structures, and healing practices. In particular, students are encouraged to practice from an anti-colonial lens in which they learn: the location of Indigenous people in the colonial context and how this context hinders Indigenous 
self-determination and development; about colonial oppression and its relation to parallel forms of oppression; and to confront issues of oppression in practice by advocating for partnership with Indigenous peoples on matters related to self-determination (Hart et al., 2014).

The MSW-IK program was specifically created by Indigenous social workers, scholars, and elders to train Indigenous social workers for the benefit of Indigenous communities (Hart et al., 2014). We encourage using this program as a model for how to build social work capacity for practitioners who are a part of a community to develop culturally relevant healing and social change practices in partnership with that community. Nonetheless, given the marginalization of Indigenous people, specifically, in social work, partnerships often must be built across settler/Indigenous boundaries in anticolonial research and practice (Hart et al., 2017). Hart et al. (2017) provide an excellent guide for how researchers can approach these partnerships in a way that maintains the anti-colonial and Indigenist integrity of the practice. Examining this guide, as well as other anti-colonial scholarship by Indigenous people, is an essential first step for ecosocial workers who are starting to include Indigenous knowledges.

Anti-colonial practice enacts ecosocial work principles. Ecosocial work aims to learn from Indigenous knowledges and encourages working with diverse communities while critiquing hegemony (Gray et al., 2007; Ramsay \& Boddy, 2017). Anti-colonial social work also requires a critique of colonialism and resistance to its dominance, but demands that research, interventions, and planning for Indigenous communities be led by those communities themselves (Hart et al., 2017). Such self-determination facilitates renewal of Indigenous responsibilities to the sustainable practice of Indigenous livelihoods (Alfred, 2009; Corntassel, 2012; Whyte et al., 2018). The decolonizing praxis must move beyond political awareness or symbolic gestures, and instead engage in daily truth telling and resistance to colonial encroachments, in addition to the struggles to reclaim, restore, and regenerate relationships to the land (Corntassel, 2012).

Adopting anti-colonial practice allows ecosocial work to further support Indigenous communities as they resist climate change and lead environmental movements such as the Dakota Access Pipeline resistance at Standing Rock. As ecosocial work further develops, many practitioners will grapple with not only learning from Indigenous and marginalized communities, but intentionally following the lead of those communities, especially elders and the knowledges they hold. Social workers are trained to serve as bridges between diverse stakeholders and to reduce oppressive power dynamics between professionals and communities (CASW, 2005; NASW, 2017). In order to do so, ecosocial workers must examine their own role in colonialism and resist re-enacting it in their practice. Acknowledging that social workers are part of multiple, intersecting complex systems includes recognizing that we are never acting upon a system as an outside agent; rather, we are always a part of that system (Chandler, 2014). Locating ourselves within systems of power, including colonization, requires critical reflexivity (Hart et al., 2017). 
Anti-colonialism and ecosocial work share the outlook that addressing global environmental change necessitates further examination of interlocking oppressions. Addressing the root causes of the climate crisis is essential to building resilience and achieving climate justice (Cretney, 2014; Hornborg, 2013; Movement Generation, 2013). Further, addressing root causes includes marginalized communities being able to provide for their own needs in their own way (Hart, 2009), so that they are not vulnerable to white supremacist economic coercion (Nembhard, 2014; Waziyatawin, 2012; White, 2017). Anti-colonial practice supports CSS, which enables effective collective action and social movements led by frontline communities.

\section{Conclusion}

We offer CSS as a framework by which to understand practices that have sustained communities who have experienced colonization, enslavement, exploitation, and oppression. CSS guide us to a way of living in right relationship with the Earth. Doing so is essential to building resilience (Cretney, 2014) and realigns our loyalty to the actual basis of life, the Earth, rather than a fossil fuel-powered industrial society (Waziyatawin, 2012). The de-sanctification of nature is both a key strategy of colonization and a key cause of ecological crises (Waziyatawin, 2012). In restoring communities' abilities to live in right relationship with the Earth, CSS enact climate mitigation and adaptation on a microscale. Anti-colonial practice is a framework that encourages CSS and guides us in living in right relationship with each other. As ecosocial work embraces traditional environmental knowledges, considering how mainstream social work and academia more broadly, as settler-imposed institutions (Hart et al., 2017), have constricted Indigenous knowledges and cultures is vital, particularly as settler colonialism already caused a climate change dystopia for Indigenous people. Anti-colonial social work offers a framework for addressing the root causes of environmental crisis and enabling collective survival.

\section{Notes}

1. We use global environmental change and environmental (or ecological) crisis to refer to the current large-scale changes that our planet is experiencing due to primarily human causes, including climate change. When authors cite climate change specifically, as does Whyte $(2016,2017)$, we follow their language.

2. We define and use Indigenous as: The diverse peoples who originally inhabited a particular place (in North America, this includes people referred to as Native American, American Indian/Alaska Native, and Aboriginal), whose culture, way of life, and knowledge systems developed in relationship to that place, and who are the targets of colonial logic to destroy and replace in settler colonial societies (adapted from Brewer \& Dennis, 2017).

3. Relationships and daily subsistence practices. 


\section{Disclosure statement}

No potential conflict of interest was reported by the authors. 


\section{References}

Alfred, T. (2009). Colonialism and state dependency. Journal of Aboriginal Health, 5, 42-60. Bandele, O., \& Myers, G. (2016). Roots of black agrarianism. Dismantling Racism in the Food System, 4, 1-7. Oakland, CA: Institute for Food and Development Policy.

Billiot, S., Beltran, R., Teyra, C., Fernandez, A., Black, J. C., Brown, D., ... Walters, K. (2017, January). Strengthening social responses to global environmental changes grand challenge: An indigenous approach. Roundtable conducted at Society for Social Work and Research Annual Conference, New Orleans.

Boetto, H. (2018). Transformative ecosocial work: Incorporating being, thinking, and doing in practice. In M. Pawar, W. Bowles, \& K. Bell (Eds.), Social work: Innovations and insights [Google Book Version]. Retrieved from. https://books.google.com/books?hl=en\&id=Lh9sDwAAQBAJ\&oi=fnd\&pg=PT114\&ots= eGD6c6cRop\&sig=I0IpDGYNkMhYfpHw4D4fd7jJ8fc

Boonstra, W. J. (2016). Conceptualizing power to study social-ecological interactions. Ecology and Society, 21(1), 21-32. doi:10.5751/ES-07966-210121

Brewer, J. P., \& Dennis, M. K. (2017). An offering: Lakota elders' contributions to the future of food security. Journal of Indigenous Social Development, 6(2), 1-22.

Brewer, J. P., \& Dennis, M. K. (2019). A land neither here nor there: Voices from the margins $\&$ the untenuring of Lakota lands. GeoJournal, 84(3),571 - 591.

Canadian Association of Social Workers. (2005). Code of ethics. Retrieved from https:/www.casw-acts.ca/en/Code-of-Ethics

Case, R. A. (2017). Community resilience and eco-social work practice: Insights from water activism in Guelph, Ontario, Canada. Journal of Social Work, 17(4), 391-412. doi:10.1177/1468017316644695

Chandler, D. (2014). Beyond neoliberalism: resilience, the new art of governing complexity. Resilience, 2(1), 47-63. doi:10.1080/21693293.2013.878544

Corntassel, J. (2012). Re-envisioning resurgence: Indigenous pathways to decolonization and sustainable self-determination. Decolonization: Indigeneity, Education \& Society, 1(1), 81-101.

Cretney, R. (2014). Resilience for whom? Emerging critical geographies of socio-ecological resilience. Geography Compass, 8(9), 627-640. doi:10.1111/gec3.v8.9

Dater, A., \& Merton, L. (2008). Taking root: The vision of Wangari Maathai [Motion Picture]. United States: Independent Lens.

Davoudi, S., Brooks, E., \& Mehmood, A. (2013). Evolutionary resilience and strategies for climate adaptation. Planning, Practice and Research, 28(3), 307-322. doi:10.1080/02697459.2013.787695

Fabinyi, M., Evans, L., \& Foale, S. J. (2014). Social-ecological systems, social diversity, and power: insights from anthropology and political ecology. Ecology and Society, 19(4), 28-39. doi:10.5751/ES-07029-190428 
Gray, M., Coates, J., \& Hetherington, T. (2007). Hearing indigenous voices in mainstream social work. Families in Society, 88(1), 55-66. doi:10.1606/1044-3894.3592

Hart, K., Rowe, G., Hart, M. A., Pompana, Y., Halonen, D., Cook, G., .. Coggins, K. (2014). A proposed master of social work based in indigenous knowledges program in Manitoba. Journal of Indigenous Social Development, 3(2), 1-18.

Hart, M. A. (2009). Anti-colonial Indigenous social work: Reflections on an Aboriginal approach. In G. Bruyere, M. A. Hart, \& R. Sinclair (Eds.), Wicihitowin: Aboriginal social work in Canada (pp. 25-41). Halifax, Canada: Fernwood Pub.

Hart, M. A., Straka, S., \& Rowe, G. (2017). Working across contexts: Practical considerations of doing Indigenist/anti-colonial research. Qualitative Inquiry, 23(5), 332-342. doi:10.1177/ 1077800416659084

Hornborg, A. (2013). Revelations of resilience: From the ideological disarmament of disaster to the revolutionary implications of (p)anarchy. Resilience, 1(2), 116-129. doi:10.1080/ 21693293.2013.797661

Ingalls, M. L., \& Stedman, R. C. (2016). The power problematic: exploring the uncertain terrains of political ecology and the resilience framework. Ecology and Society, 21(1), 6-16. doi:10.5751/ES-08124-210106

Intergovernmental Panel on Climate Change. (2018, October 8). Summary for policymakers of IPCC special report on global warming of $1.5^{\circ} \mathrm{C}$ approved by governments [Press Release]. Retrieved from https://www.ipcc.ch/pdf/session48/pr 181008 P48 spm en.pdf

Klinenberg, E. (2015). Heat wave: A social autopsy of disaster in Chicago. Chicago, IL: University of Chicago Press.

Krings, A., Kornberg, D., \& Lane, E. (2019). Organizing under austerity: How residents' concerns became the Flint Water Crisis. Critical Sociology, 45(4-5), 583-597. doi: $10.1177 / 0896920518757053$

Krings, A., Spencer, M. S., \& Jimenez, K. (2014). Organizing for environmental justice: From bridges to taro patches. In S. Dutta \& C. Ramanathan (Eds.), Governance, development, and social work (pp. 186-200). New York, NY: Routledge.

Krings, A., \& Thomas, H. (2018). Integrating green social work and the U.S. environmental justice movement: An introduction to community benefits agreements. In L. Dominelli (Ed.), The Routledge handbook of green social work (pp. 397-406). New York, NY: Routledge.

Krings, A., Victor, B. G., Mathias, J., \& Perron, B. E. (2018). Environmental social work in the disciplinary literature, 1991 - 2015. International Social Work, 002087281878839. doi:10.1177/0020872818788397

Mason, L. R., Shires, M. K., Arwood, C., \& Borst, A. (2017). Social work research and global environmental change. Journal of the Society for Social Work and Research, 8(4), 645-672. doi:10.1086/694789 
Movement Generation. (2013). The work of love and the love of work: Resilience-based organizing as a path forward. Retrieved from https://movementgeneration.org/wpcontent/uploads/2014/03/WorkOfLoveAndLoveOfW ork.pdf

Mullaly, R. (1997). Structural social work. Toronto, Canada: Oxford University Press.

Närhi, K., \& Matthies, A.-L. (2016). Conceptual and historical analysis of ecological social work. In J. McKinnon \& M. Alston (Eds.), Ecological social work: Towards sustainability (pp. 21-38). London, UK: Palgrave MacMillan.

National Association of Social Workers. (2017). Preamble to the code of ethics. Retrieved from https://www.socialworkers.org/About/Ethics/Code-of-Ethics/Code-of-Ethics-English

Nembhard, J. G. (2014). Collective courage: A history of African American cooperative economic thought and practice. University Park, PA: Penn State University Press.

Norton, C. L. (2012). Social work and the environment: An ecosocial approach. International Journal of Social Welfare, 21(3), 299-308. doi:10.1111/j.1468-2397.2011.00853.x

Peeters, J. (2012a). Social work and sustainable development. Towards a social-ecological practice model. Journal of Social Intervention: Theory and Practice, 21(3), 5-26.

Peeters, J. (2012b). The place of social work in sustainable development: Towards ecosocial practice. International Journal of Social Welfare, 21(3), 287-298. doi:10.1111/j.14682397.2011.00856.x

Peña, D. G. (2005). Autonomy, equity, and environmental justice. In D. N. Pellow \& R. J. Brulle (Eds.), Power, justice, and the environment: A critical appraisal of the environmental justice movement (pp. 131-151). Cambridge, MA: MIT Press.

Quizar, J. (2018). Working to live: Black-led farming in Detroit's racialized economy. In L. Nishime \& K. D. Hester Williams (Eds.), Racial ecologies (pp. 76-89). Seattle, WA: University of Washington.

Ramsay, S., \& Boddy, J. (2017). Environmental social work: A concept analysis. The British Journal of Social Work, 47(1), 68-86.

Said, E. W. (2012). Culture and Imperialism. New York, NY: Random House.

Schneider-Mayerson, M. (2015). Peak oil: Apocalyptic environmentalism and libertarian political culture. Chicago, IL: University of Chicago Press.

Sharpe, C. (2016). In the wake: On blackness and being. Durham, NC: Duke University Press.

Smith, L. (1999). Decolonizing methodologies: Indigenous peoples and research. New York, NY: Zed Books.

Teixeira, S., \& Krings, A. (2015). Sustainable social work: An environmental justice framework for social work education. Social Work Education, 34(5), 513-527. doi:10.1080/ 02615479.2015.1063601

Thornton, R. (2000). Population history of native North Americans. In M. R. Haines \& R. H. Steckel (Eds.), A population history of North America (pp. 12-50). Cambridge, UK: Cambridge University Press. 
Tierney, K. (2015). Resilience and the neoliberal project: Discourses, critiques, practices — and Katrina. American Behavioral Scientist, 59(10), 1327-1342. doi:10.1177/0002764215591187

Ungar, M., Ghazinour, M., \& Richter, J. (2013). Annual research review: What is resilience within the social ecology of human development? Journal of Child Psychology and Psychiatry, 54(4), 348-366. doi:10.1111/jcpp.12025

Vrasti, W., \& Michelsen, N. (2017). Introduction: On resilience and solidarity. Resilience, 5 (1), 1-9. doi:10.1080/21693293.2016.1228155

Walsh-Dilley, M., Wolford, W., \& McCarthy, J. (2016). Rights for resilience: Food sovereignty, power, and resilience in development practice. Ecology \& Society, 21(1), 11-20. doi:10.5751/ES-07981-210111

Waziyatawin. (2012). The paradox of Indigenous resurgence at the end of empire. Decolonization: Indigeneity, Education \& Society, 1(1), 68-85.

White, M. M. (2011). D-Town Farm: African American resistance to food insecurity and the transformation of Detroit. Environmental Practice, 13(4), 406-417. doi:10.1017/ S1466046611000408

White, M. M. (2017). “A pig and a garden": Fannie lou hamer and the freedom farms cooperative. Food and Foodways, 25(1), 20-39. doi:10.1080/07409710.2017.1270647

Whyte, K., Caldwell, C., \& Schaefer, M. (2018). Indigenous lessons about sustainability are not just for "all humanity.". In J. Sze (Ed.), Sustainability: Approaches to environmental justice and social power (pp. 149-179). New York, NY: NYU Press.

Whyte, K. P. (2016). Is it colonial déjà vu? Indigenous peoples and climate injustice. In J. Adamson, M. Davis, \& H. Huang (Eds.), Humanities for the environment: Integrating knowledges, forging new constellations of practice (pp. 88-104). New York, NY: Routledge.

Whyte, K. P. (2017). Indigenous climate change studies: Indigenizing futures, decolonizing the Anthropocene. English Language Notes, 55(1-2), 153-162. doi:10.1215/00138282$55.1-2.153$

Wolfe, P. (2006). Settler colonialism and the elimination of the native. Journal of Genocide Research, 8(4), 387-409. doi:10.1080/14623520601056240 